\title{
Comparative Studies on the Corrosion Inhibition of Three Different Organic Heterocyclic Compounds as Corrosion Inhibitors for Mild Steel in Hydrochloric Acid
}

\author{
Zineb Tribak ${ }^{1}$, Mohammed Khalid Skalli ${ }^{1}$, Amal Haoudi ${ }^{1}$, Youssef Kandri Rodi ${ }^{1}$, Omar Senhaji ${ }^{2}$ \\ ${ }^{1}$ Laboratory of Applied Organic Chemistry, Faculty of Sciences and Technology, B.P. 2202, Sidi Mohamed \\ Ben Abdellah University, Fez Morocco. \\ ${ }^{2}$ Biomolecular and Macromolecular Chemistry Team, Faculty of Sciences B.P. 11201, Moulay Ismail \\ University, Meknes Morocco.
}

*Corresponding author: Zineb Tribak, email: tribak.zineb@gmail.com, Tel: +212 659899497

Received July $1^{\text {st }}, 2020$; Accepted August $14^{\text {th }}, 2020$.

DOI: http://dx.doi.org/10.29356/jmcs.v64i4.1247

\begin{abstract}
Three organic inhibitors based 5-Chloroisatin's bases, namely, 1-allyl-5-chloro-indoline-2,3-dione ( $\mathrm{TZ}_{\mathrm{ACI}}$ ). 5-chloro-1-(2-(dimethylamino) ethyl) indoline-2,3-dione $\left(\mathrm{TZ}_{\mathrm{CDI}}\right)$,5-chloro-1-octylindoline-2,3-dione $\left(\mathrm{TZ}_{\mathrm{COI}}\right)$ were influence on corrosion inhibition of mild steel in $1.0 \mathrm{M}$ hydrochloric acid solution. The inhibition efficiency increased with the increase of a compound concentration in the case of these three inhibitors, which have the mixed type behavior proposed by the polarization studies. Impedance measurements showed that after the addition of inhibitors, charge-transfer resistance increased and double-layer capacitance decreased, involving increased inhibition efficiency. The adsorption of three inhibitors on a steel surface obeyed Langmuir model. Free energy of adsorption showed that the type of adsorption was physical for $\mathrm{TZ}_{\mathrm{ACI}}$ and chemical for the $\mathrm{TZ}_{\mathrm{CDI}}, \mathrm{TZ}_{\mathrm{COI}}$. Scanning electron microscopic analyses confirm the formation of the protective film on the surface.
\end{abstract}

Keywords: Organic inhibitors; mild steel; corrosion; hydrochloric acid; the inhibition efficiency.

Resumen. Tres inhibidores orgánicos basados en las bases de la 5-Cloroisatina, a saber, 1-alil-5-cloro-indolina2,3-diona $\left(\mathrm{TZ}_{\mathrm{ACI}}\right)$, 5-cloro-1-(2-(dimetilamino) etil) indolina-2,3-diona ( $\mathrm{TZ}_{\mathrm{CDI}}$ ) y 5-cloro-1-octilindolina-2,3diona $\left(\mathrm{TZ}_{\mathrm{COI}}\right)$ tuvieron influencia en la inhibición de la corrosión del acero dulce en una solución de ácido clorhídrico 1.0M. La eficiencia de la inhibición aumentó con el incremento de la concentración del compuesto en el caso de estos tres inhibidores, que tienen el comportamiento de tipo mixto propuesto por los estudios de polarización. Las mediciones de impedancia mostraron que después de la adición de los inhibidores, la resistencia de transferencia de carga aumentó y la capacitancia de doble capa disminuyó, lo que implica una mayor eficiencia de inhibición. La adsorción de tres inhibidores en una superficie de acero obedeció al modelo de Langmuir. La energía libre de adsorción mostró que el tipo de adsorción era física para el $\mathrm{TZ}_{\mathrm{ACI}}$ y química para el $\mathrm{TZ}_{\mathrm{CDI}}, \mathrm{TZ}_{\mathrm{COI}}$. Los análisis de microscopía electrónica de barrido confirman la formación de la película protectora en la superficie.

Palabras clave: Inhibidores orgánicos, acero dulce, corrosión, ácido clorhídrico, eficiencia de inibición. 


\section{Introduction}

The use of synthetic corrosion inhibitors are significant products widely used in various industrials sectors especially in the pharmaceutical, petrochemical, generation power industries and water treatment plants. [1] In most case, heterocyclic organic compounds have been reported as effective inhibitors against corrosion phenomena for mild steel in acidic media [2] mainly depends on their abilities to be adsorbed on the metal surface with the aromatic rings and polar functional groups acting as reactive centers. [3] At a recent time, 5Chloroisatin and its derivatives are ones of the conventional organic compounds [4-9] which have temped much attention for their anticorrosion properties in various media [10] and other applications. [11-14]

The aim of this present study was to compare the anticorrosion potential of these three synthesized 5Chloroisatin derivatives $\mathbf{T Z}$ ACI, $\mathbf{T Z}$ CDI and $\mathbf{T Z}$ Cor in Hydrochloric acid $(1.0 \mathrm{M})$ media using corrosion rate method, electrochemical research-impedance and polarization measurements. Morphological study has been done using scanning electron microscope (SEM).

\section{Experimental}

\section{Inhibitor synthesis}

The inhibitors used were 1-allyl-5-chloro-indoline-2,3-dione ( $\left.\mathrm{TZ}_{\mathrm{ACI}}\right)$, [15] 5-chloro-1- (2(dimethylamino) ethyl) indoline-2,3-dione $\left(\mathrm{TZ}_{\mathrm{CDI}}\right)$, and 5-chloro-1-octylindoline-2,3-dione $\left(\mathrm{TZ}_{\mathrm{COI}}\right)$. The inhibitors were synthesized in the laboratory according to the published method [16-19] and they are represented in the table 1 below.

Table 1. Chemical structures of the investigated compounds.

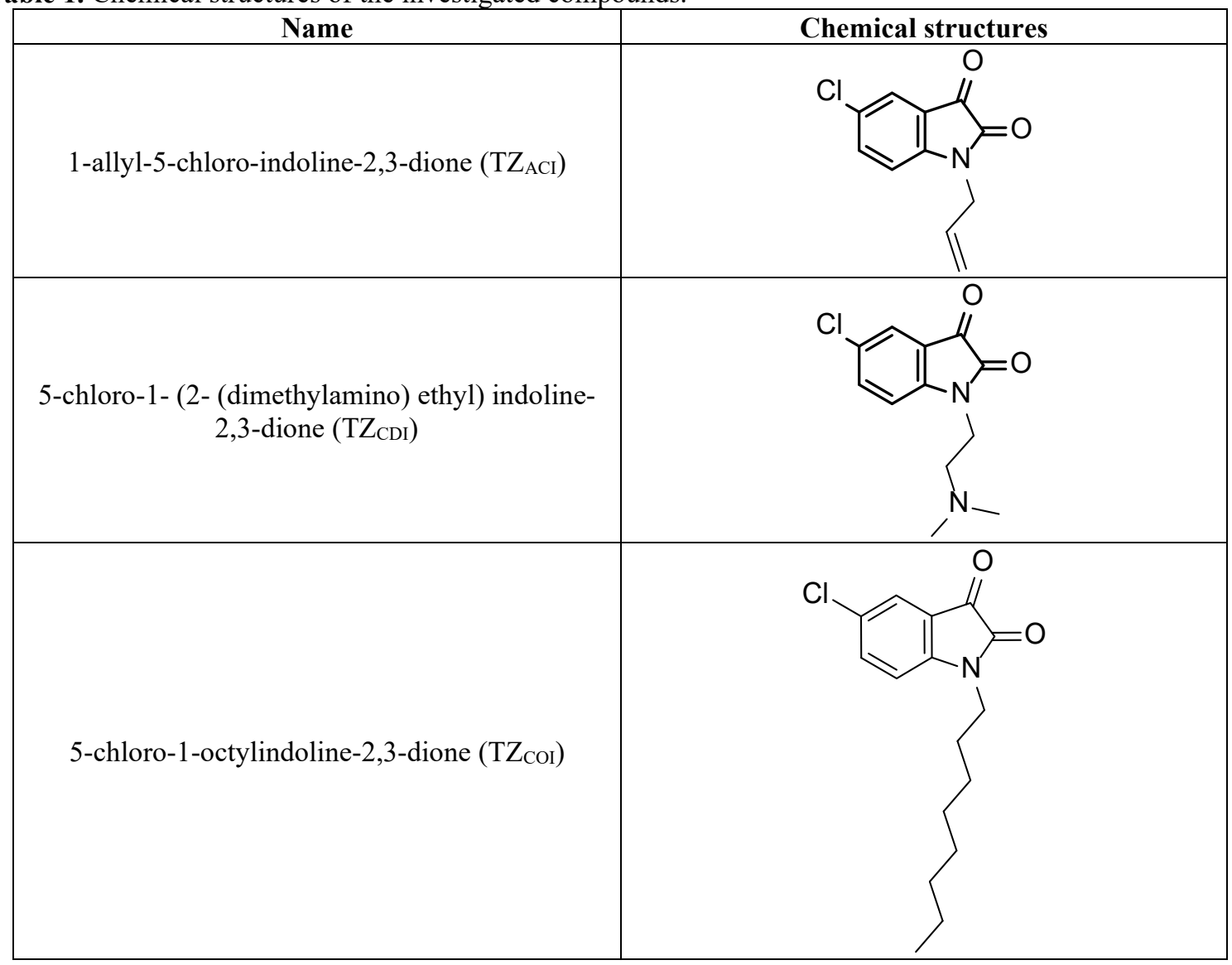




\section{Materials}

Mild steel specimens used as test materials contain the following composition (in wt $\%$ ): $0.370 \% \mathrm{C}$, $0.230 \% \mathrm{Mn} 0.680 \% \mathrm{Si}, 0.016 \% \mathrm{~S}, 0.077 \% \mathrm{Cr}, 0.011 \% \mathrm{Ti}, 0.059 \% \mathrm{Ni}, 0.009 \% \mathrm{Co}, 0.160 \%$ of $\mathrm{Cu}$ and the remainder iron $(\mathrm{Fe})$. The steel samples were pre-treated prior to the experiments by grinding with emery paper (SiC) $(400,600$ and 1200), rinsed with distilled water, degreased in acetone, washed again with bidistilled water and then dried at room temperature before use.

\section{Solutions}

Solutions of the tested compounds in optimized concentration range of $10^{-6} \mathrm{M}$ to $10^{-3} \mathrm{M}$ were prepared from stock solution made of using $1.0 \mathrm{M} \mathrm{HCl}$ by dilution of analytical grade $37 \% \mathrm{HCl}$ with distilled water.

\section{Experimental techniques}

Weight loss experiments, electrochemical measurements and scanning electron microscopy (SEM) studies were carried out according to the procedure described elsewhere by Tribak et al. [20-22]

\section{Results and discussion}

\section{Weight loss studies}

The values of corrosion inhibition efficiency $(\boldsymbol{\eta}(\boldsymbol{\%}))$ and corrosion rate $\left(\boldsymbol{C}_{\boldsymbol{R}}\right)$ with and without different concentrations of 5-Chloroisatin derivatives for mild steel in $1.0 \mathrm{M} \mathrm{HCl}$ are presented in Tables 2.

It is clear from the Table 2 that, as the concentration reduced as, the corrosion rate decreased, and inhibition efficiency increased for all the three inhibitors. The increased inhibition efficiency at higher inhibitor concentration may be due to the adsorption of inhibitor molecules on mild steel surface. [23]

The inhibition efficiency of the three studied molecules follows the order: $\mathbf{T Z} \mathbf{Z}_{\mathbf{C D I}}>\mathbf{T} \mathbf{T Z}_{\mathbf{A C I}}>\mathbf{T Z} \mathbf{C O I}$. This order can be explained by the presence of the end-group attached to the phenyl ring of the Indole moiety. [24]

Table 2. Weight loss data in the absence and presence of inhibitors in $1.0 \mathrm{M} \mathrm{HCl}$ at different concentrations.

\begin{tabular}{|c|c|c|c|}
\hline $\begin{array}{c}\text { Concentration } \\
\text { (M) }\end{array}$ & $\begin{array}{c}C_{R} \\
\left(\mathrm{mg}^{2} \mathrm{~cm}^{2} \cdot \mathrm{h}^{1}\right)\end{array}$ & $\begin{array}{c}\eta \\
(\%)\end{array}$ & \\
\hline & $1.0 \mathrm{M} \mathrm{HCl}$ & 0.82 & -- \\
\hline $\mathbf{T} \mathbf{Z}_{\mathrm{ACI}}$ & $\begin{array}{l}10^{-3} \\
10^{-4} \\
10^{-5} \\
10^{-6}\end{array}$ & $\begin{array}{l}0.07 \\
0.15 \\
0.21 \\
0.32\end{array}$ & $\begin{array}{l}91 \\
82 \\
74 \\
61\end{array}$ \\
\hline & $1.0 \mathrm{M} \mathrm{HCl}$ & 0.45 & -- \\
\hline$T Z_{C D I}$ & $\begin{array}{l}10^{-3} \\
10^{-4} \\
10^{-5} \\
10^{-6}\end{array}$ & $\begin{array}{l}0.04 \\
0.07 \\
0.22 \\
0.24\end{array}$ & $\begin{array}{l}91 \\
83 \\
51 \\
46\end{array}$ \\
\hline $\mathbf{T Z}_{\mathrm{COI}}$ & $\begin{array}{l}1.0 \mathrm{M} \mathrm{HCl} \\
10^{-3} \\
10^{-4} \\
10^{-5} \\
10^{-6}\end{array}$ & $\begin{array}{l}0.82 \\
0.08 \\
0.13 \\
0.23 \\
0.34\end{array}$ & $\begin{array}{l}-- \\
90 \\
84 \\
72 \\
59\end{array}$ \\
\hline
\end{tabular}




\section{Electrochemical measurements}

\section{Polarization studies}

In this study, the potentiodynamic polarization experiments were performed to achieve information about the kinetics of anodic and cathodic reactions[25].

Potentiodynamic polarization curves with and without different concentrations of $\mathbf{T Z} \mathbf{Z}_{\mathbf{A C I}}, \mathbf{T} \mathbf{Z}_{\mathbf{C D I}}$ and $\mathbf{T Z}_{\mathbf{C O}}$ at $308 \mathrm{~K}$ are shown in Fig. 1, and their electrochemical corrosion kinetic parameters such as corrosion potential ( $\left.\boldsymbol{E}_{\text {corr }}\right)$, corrosion current $\left(\boldsymbol{I}_{\mathbf{c o r r}}\right)$, cathodic Tafel slopes $\left(\boldsymbol{\beta}_{\mathbf{c}}\right)$ and percentage of $\mathbf{E}_{\mathbf{p}}$ are given in Table 3.
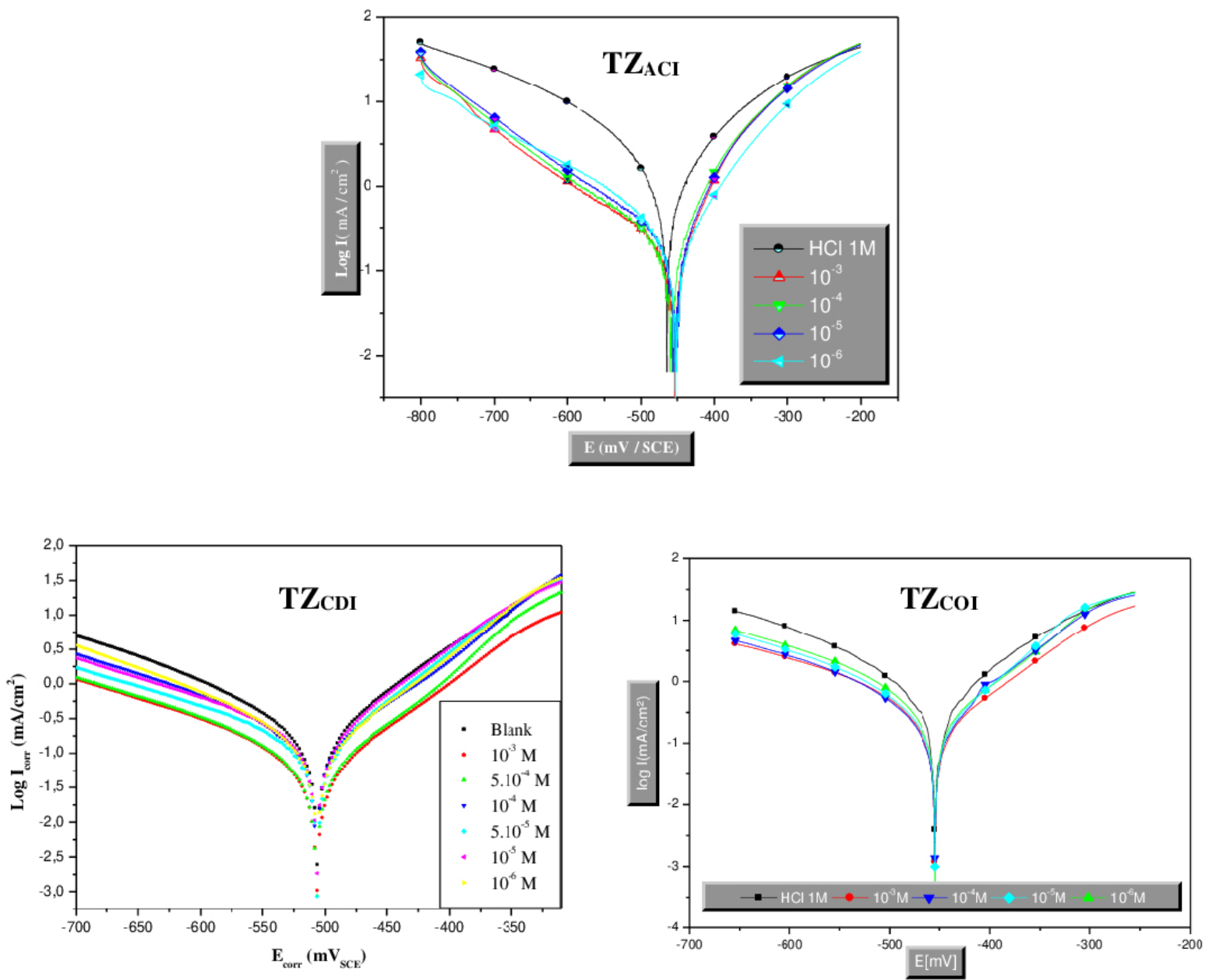

Fig. 1. Potentiodynamic polarization curves for mild steel in $1.0 \mathrm{M} \mathrm{HCl}$ in the absence and the presence of different concentrations of the three compounds. 
Table 3. Potentiodynamic polarization parameters for the corrosion of mild steel in $1.0 \mathrm{M} \mathrm{HCl}$ in absence and presence of different concentrations of $\mathbf{T Z} \mathbf{Z}_{\mathbf{A C I}}, \mathbf{T} \mathbf{Z}_{\mathbf{C D I}}$ and $\mathbf{T Z} \mathbf{Z}_{\mathbf{C O I}}$ at $308 \mathrm{~K}$.

\begin{tabular}{|c|c|c|c|c|c|}
\hline \multirow{3}{*}{ Inhibitors } & $\begin{array}{c}\text { Concentration } \\
(\mathrm{M})\end{array}$ & $\begin{array}{c}-\boldsymbol{E}_{\text {corr }} \\
(\mathrm{mV} / \mathrm{SCE})\end{array}$ & $\begin{array}{c}\boldsymbol{I}_{\text {corr }} \\
\left(\mu \mathrm{A} / \mathrm{cm}^{2}\right)\end{array}$ & $\begin{array}{c}-\boldsymbol{\beta} \mathbf{c} \\
\left(\mu \mathrm{A} / \mathrm{cm}^{2}\right)\end{array}$ & $\begin{array}{c}\mathbf{E p} \\
(\%)\end{array}$ \\
\hline \multirow{3}{*}{ Blank } & 1 & 464 & 1386 & 184 & -- \\
\hline \multirow{3}{*}{ ZZ $_{\text {ACI }}$} & $10^{-6}$ & 452 & 239 & 159 & 81 \\
\cline { 2 - 6 } & $10^{-5}$ & 454 & 206 & 173 & 83 \\
\cline { 2 - 6 } & $10^{-4}$ & 459 & 198 & 174 & 85 \\
\cline { 2 - 6 } & $10^{-3}$ & 453 & 157 & 184 & 88 \\
\hline \multirow{3}{*}{ Blank } & 1 & 506 & 172.4 & 3818 & -- \\
\hline & $10^{-6}$ & 503 & 2114 & 174 & 44 \\
\cline { 2 - 6 } & $10^{-5}$ & 499 & 1885 & 175 & 51 \\
\cline { 2 - 6 } & $10^{-4}$ & 498 & 1138 & 186 & 70 \\
\hline \multirow{2}{*}{ Blank } & $10^{-3}$ & 483 & 761 & 197 & 80 \\
\hline \multirow{2}{*}{ TZCOI } & 1 & 465 & 1387 & 184 & -- \\
\cline { 2 - 6 } & $10^{-6}$ & 461 & 612 & 177 & 56 \\
\cline { 2 - 6 } & $10^{-5}$ & 459 & 401 & 193 & 71 \\
\cline { 2 - 6 } & $10^{-4}$ & 455 & 273 & 178 & 80 \\
\cline { 2 - 6 } & $10^{-3}$ & 457 & 143 & 172 & 90 \\
\hline
\end{tabular}

It is clear from these polarization plots that introduction of inhibitors into corrosive medium exerted significant effect on both anodic and cathodic reactions indicating that these 5-Chloroisatin derivatives reduced the anodic mild steel dissolution and also retarded the cathodic hydrogen evolution reaction. [26] Further, from Table 3 it can also be seen that the presence of inhibitors decreases the value of corrosion current density (Icorr); this decrease highlights the inhibition property $\mathbf{E}_{\mathbf{p}}(\mathbf{\%})$ of these molecules. Also in the presence of 5Chloroisatin derivatives the shift in $\boldsymbol{E}_{\text {corr }}$ values is towards more negative side, but it is less than $85 \mathrm{mV}$, which proposed mixed type behaviour of inhibitors. [27]

\section{Electrochemical impedance spectroscopy}

Impedance spectra of mild steel in $1.0 \mathrm{M} \mathrm{HCl}$ containing various concentrations of the three inhibitors at $308 \mathrm{~K}$ are shown in Fig. 2.

The Nyquist plots for inhibited and uninhibited specimens give semicircles which indicate that studied inhibitors molecules behave as interface inhibitors. They inhibit corrosion by adsorbing at metal/electrolyte interface. [28] The diameter of capacitive loop increased with increase in inhibitor concentration, suggesting the improved inhibition efficiency of these molecules $\mathbf{T} \mathbf{Z}_{\mathbf{A C I}}, \mathbf{T Z} \mathbf{Z}_{\mathbf{C D I}}$ and $\mathbf{T} \mathbf{Z}_{\mathbf{C O I}}$ at higher inhibitor concentrations.

Table 4 showed the electrochemical impedance spectroscopy (EIS) parameters in the absence and the presence of the three corrosion inhibitors of mild steel in $1.0 \mathrm{M} \mathrm{HCl}$. It can be observed that the charge transfer resistance $\left(\boldsymbol{R}_{t}\right)$ value increased with an increase in the concentration of the $\mathbf{T Z} \mathbf{Z}_{\mathbf{A C I}}, \mathbf{T Z} \mathbf{Z}_{\mathbf{C D I}}$ and $\mathbf{T} \mathbf{Z}_{\mathbf{C O}}$ inhibitors, while the values of the double-layer capacitance $\left(\boldsymbol{C}_{\boldsymbol{d l}}\right)$ of the interface started decrease, with an increase in the inhibitors concentrations. The rise in $\boldsymbol{R}_{\mathrm{ct}}$ data, and as a result of the inhibition efficiency $\mathbf{E}_{\mathbf{R t}}(\boldsymbol{\%})$, may be due to the gradual change molecules of water by the inhibitor molecules adsorption on the mild steel surface to form a film 
adherent on surface. [29] For this reason, the decrease in $\boldsymbol{C}_{\boldsymbol{d l}}$ for all molecules indicates a reduction in the local dielectric constant or an increase in the thickness of the electrical double layer. [30]
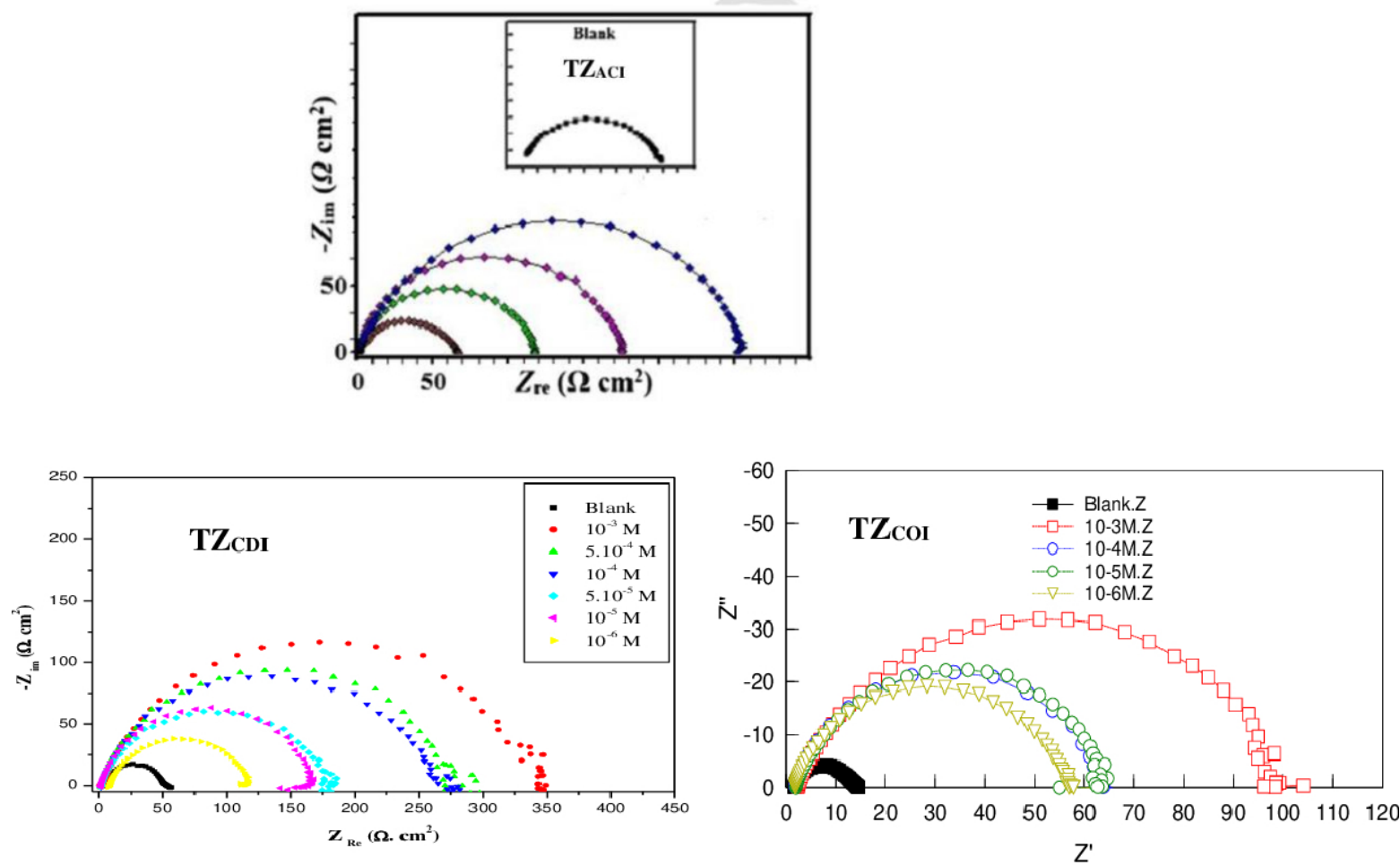

Fig. 2. Impedance diagram for mild steel in $1.0 \mathrm{M} \mathrm{HCl}$ in the presence and absence of different concentrations of the inhibitors.

Table 4. Impedance parameters for the corrosion of mild steel in $1.0 \mathrm{M} \mathrm{HCl}$ in absence and presence of different concentrations of inhibitors.

\begin{tabular}{|c|c|c|c|c|}
\hline Inhibitors & $\begin{array}{l}\text { Concentration } \\
(\mathrm{M})\end{array}$ & $\begin{array}{l}\boldsymbol{R}_{\boldsymbol{t}} \\
\left(\Omega \cdot \mathrm{cm}^{2}\right)\end{array}$ & $\begin{array}{l}C_{d l} \\
\left(\mu \mathrm{F} \cdot \mathrm{cm}^{-2}\right)\end{array}$ & $\begin{array}{l}\mathbf{E}_{\mathbf{R t}} \\
(\%) \\
\end{array}$ \\
\hline $1.0 \mathrm{M} \mathrm{HCl}$ & 1 & 10 & 200 & -- \\
\hline \multirow{4}{*}{$\mathbf{T Z}$ ACI } & $10^{-6}$ & 60 & 74 & 83 \\
\hline & $10^{-5}$ & 110 & 46 & 91 \\
\hline & $10^{-4}$ & 175 & 38 & 94 \\
\hline & $10^{-3}$ & 250 & 31 & 96 \\
\hline $1.0 \mathrm{M} \mathrm{HCl}$ & 1 & 4.88 & 66 & -- \\
\hline \multirow{4}{*}{ TZCDI } & $10^{-6}$ & 2.39 & 68 & 59 \\
\hline & $10^{-5}$ & 2.67 & 62 & 68 \\
\hline & $10^{-4}$ & 1.08 & 59 & 82 \\
\hline & $10^{-3}$ & 2.92 & 46 & 85 \\
\hline $1.0 \mathrm{M} \mathrm{HCl}$ & 1 & 14.78 & 71 & - \\
\hline \multirow{4}{*}{$\mathbf{T Z}_{\mathrm{COI}}$} & $10^{-6}$ & 52.35 & 69 & 72 \\
\hline & $10^{-5}$ & 57.51 & 61 & 74 \\
\hline & $10^{-4}$ & 65.51 & 52 & 77 \\
\hline & $10^{-3}$ & 97.09 & 50 & 85 \\
\hline
\end{tabular}




\section{Adsorption studies}

The anticorrosion activities of organic inhibitors mainly depend on the adsorption of inhibitor molecules on the surface metallic to construct a compact barrier film. [31] Hence, it is essential to know the adsorption isotherm that can give valuable information on the interaction of inhibitor and metal surface. studied.

As can be seen from Fig. 3, straight lines were obtained by plotting $\mathrm{C} / \theta$ vs. $\mathrm{C}$ at all concentrations
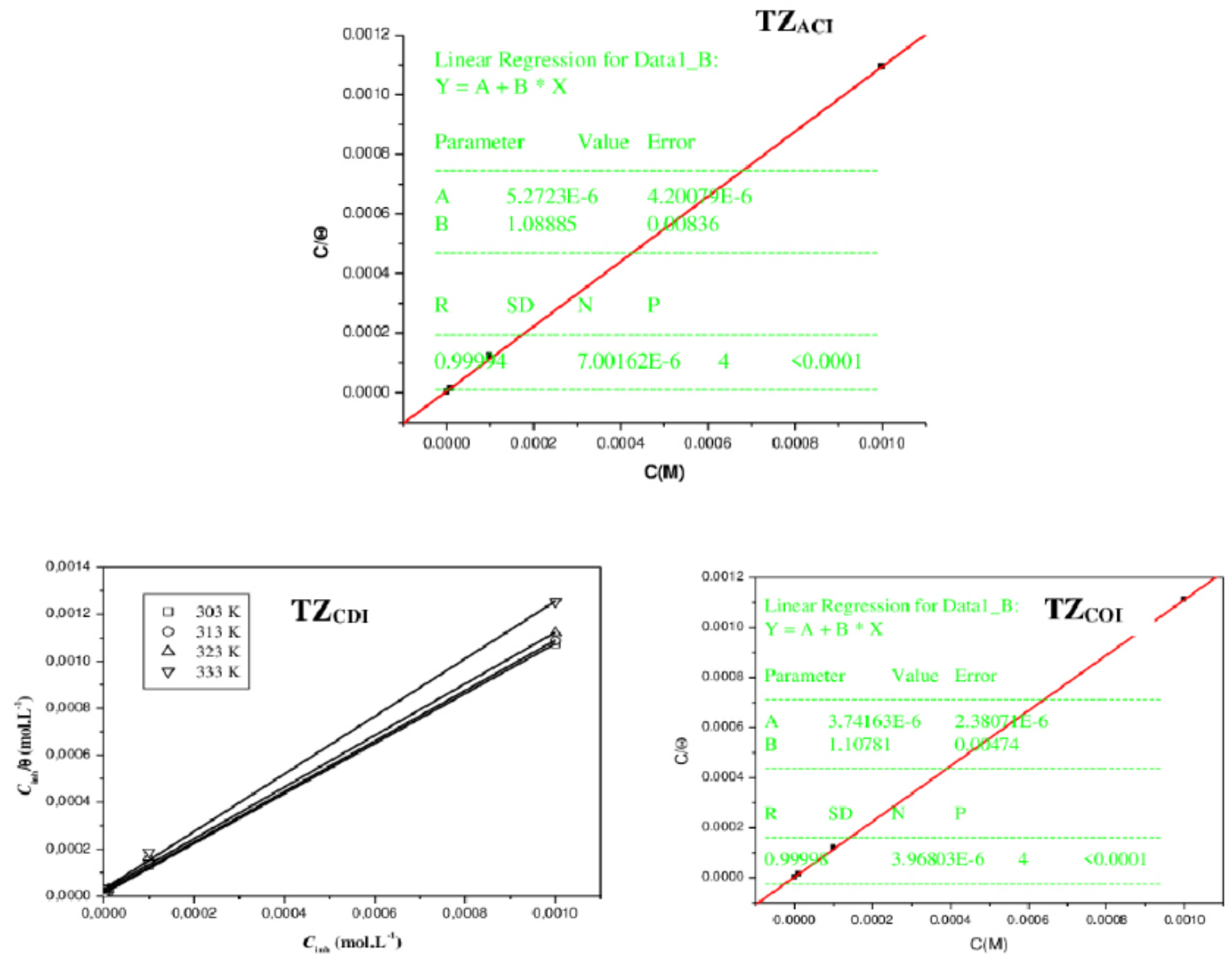

Fig. 3. Langmuir adsorption isotherm plots for the adsorption of $\mathrm{TZ}_{\mathrm{ACI}}, \mathrm{TZ}_{\mathrm{CDI}}$ and $\mathrm{TZ} \mathrm{C}_{\mathrm{COI}}$ on mild steel surface in $1.0 \mathrm{M} \mathrm{HCl}$ at $308 \mathrm{~K}$ temperature.

This indicates that the three inhibitors $\mathbf{T} Z_{\mathbf{A C I}}, \mathbf{T} \mathbf{Z}_{\mathbf{C D I}}$ and $\mathbf{T} \mathbf{Z}_{\mathbf{C O I}}$ are adsorbed on the mild steel surface, according to the Langmuir adsorption isotherm as the best fit. The data of $\mathbf{D} \boldsymbol{G}^{\circ}$ ads and $\boldsymbol{K}_{\text {ads }}$ were calculated and are reported in Table 5.

Table 5. Adsorption thermodynamic parameters in the absence and presence of various concentrations of inhibitors.

\begin{tabular}{|l|l|l|l|l|}
\hline Inhibitor & Slope & $\mathbf{R}^{\mathbf{2}}$ & $\begin{array}{l}\boldsymbol{K}_{\text {ads }} \\
\left(\mathbf{M}^{-1}\right)\end{array}$ & $\begin{array}{l}\mathbf{D} G_{\text {ads }}^{\circ} \\
\left(\mathbf{k J ~ m o l}^{-1}\right)\end{array}$ \\
\hline $\mathbf{T Z}_{\text {ACI }}$ & 1.08 & 0.999 & $1.910^{5}$ & -17.97 \\
\hline $\mathbf{T Z}_{\text {CDI }}$ & 1.06 & 0.999 & $1.610^{5}$ & -40.45 \\
\hline $\mathbf{T Z}_{\text {COI }}$ & 1.10 & 0.999 & $2.610^{5}$ & -42.26 \\
\hline
\end{tabular}


Meanwhile, the negative values of $\mathbf{D} \boldsymbol{G}^{\circ}$ ads suggest a spontaneous adsorption process[32]. The examination of data listed in Table 5 revealed that the adsorption process of the $\mathbf{T} \mathbf{Z}_{\mathbf{C D I}}$ and $\mathbf{T Z} \mathbf{Z}_{\mathbf{C O}}$ molecules $\left(<40 \mathrm{~kJ} \mathrm{~mol}^{-1}\right)$ on mild steel surface involves chemisorption[33]. On the other hand the measured data of free energy of the inhibitor $\mathbf{T Z} \mathbf{Z}_{\mathbf{A C I}}$ is $20 \mathrm{~kJ} \mathrm{~mol}^{-1}$ or less, which lead to that adsorption of this organic assembled inhibitor on mild steel surface takes place via physisorption[34].

\section{Morphology examination of mild steel by SEM}

Optical microscopic surface analysis [35] with and without inhibitors $\mathbf{T Z}_{\mathbf{A C I}}, \mathbf{T Z}_{\mathbf{C D I}}$ and $\mathbf{T Z} \mathbf{Z}_{\mathbf{C O I}}$ at 308 $\mathrm{K}$ are presented in Fig. 4((a)-(e)). The polished and smooth surface of mild steel before immersion in $1.0 \mathrm{M}$ $\mathrm{HCl}$ is shown in Fig. 4(a). It can be clearly observed from Fig. 4(b) that the mild steel surface processed without the inhibitors is severely corroded and a number of pits are distributed over the metal surface. However, the surface images in the presence of inhibitors (Figures 4(c)-(e)) show close resemblance to bare the outside of the mild steel, which indicate that in the presence of inhibitors, the corrosion process has been decreased to a great extent. This observation demonstrates the good protective potential of $\mathbf{T Z} \mathbf{A C I}_{\mathbf{A C}} \mathbf{T} \mathbf{Z}_{\mathbf{C D I}}$ and $\mathbf{T} \mathbf{Z}_{\mathbf{C O}}$ to behave as good inhibitors for the surface tested in acidulous media. [36]
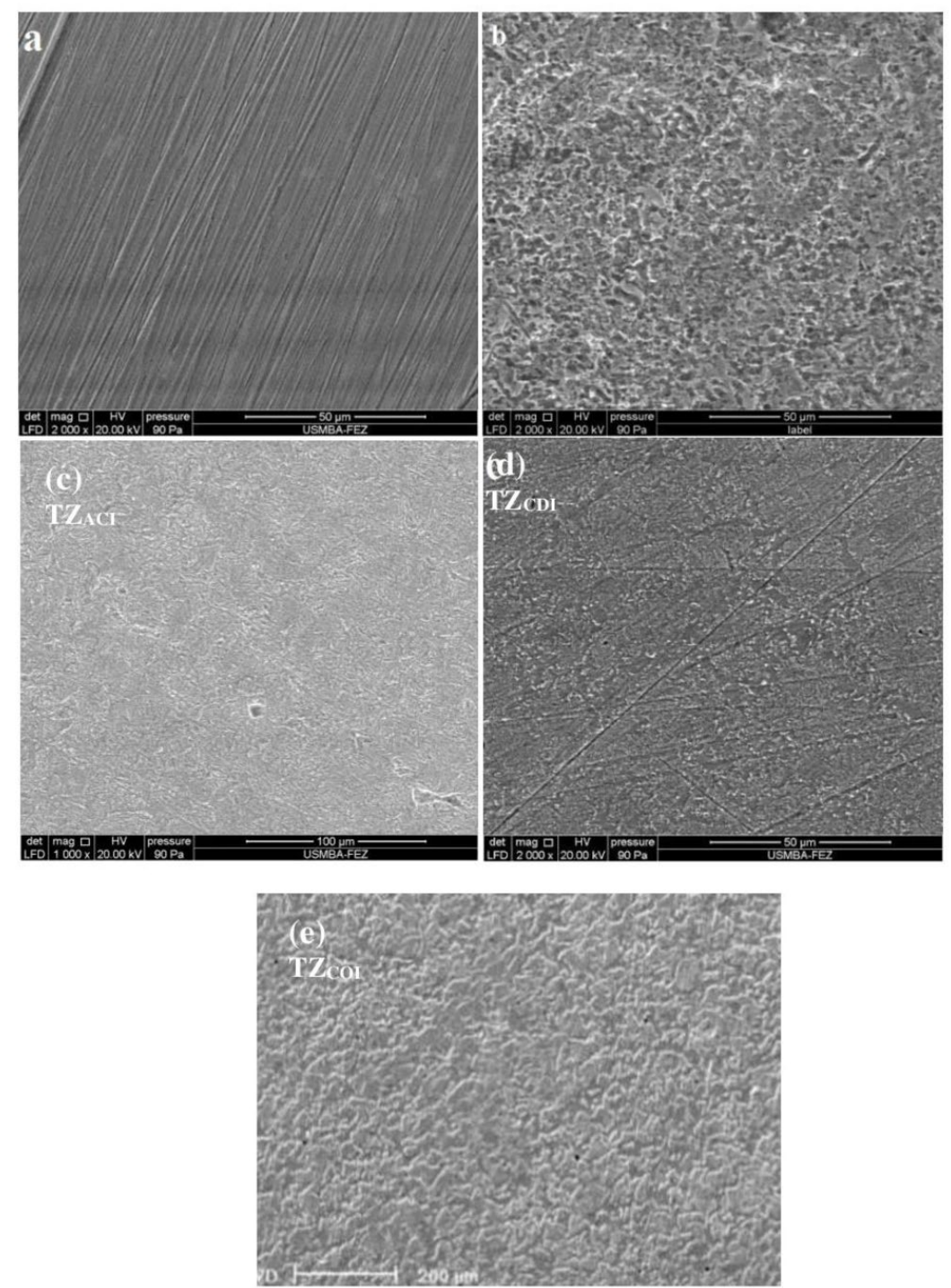

Fig. 4. SEM images of mild steel samples after immersion in $1.0 \mathrm{M} \mathrm{HCl}$ for 6hours at $308 \mathrm{~K}$ (a) before (b) without inhibitors, (c) with inhibitor $1\left(\mathbf{T Z}_{\mathbf{A C I}}\right)(\mathbf{d})$ with inhibitor $2\left(\mathbf{T Z}_{\mathbf{C D I}}\right)(\mathbf{e})$ with inhibitor 3(TZCOI). 


\section{Conclusion}

From the above studies on 5-Chloroisatin derivatives as corrosion inhibitors using gravimetric, electrochemical impedance spectroscopy (EIS), potentiodynamic polarization, scanning electron microscopy (SEM), it is presented the following conclusions:

a) The expired three compounds 1-allyl-5-chloro-indoline-2,3-dione ( $\left.\mathbf{T Z}_{\mathbf{A C I}}\right)$, 5-chloro-1-(2(dimethylamino) ethyl) indoline-2,3-dione $\left(\mathbf{T Z}_{\mathbf{C D I}}\right)$ and 5-chloro-1-octylindoline-2,3-dione (TZCoI) acts as good and efficient corrosion inhibitors for the corrosion of mild steel in $1.0 \mathrm{M}$ $\mathrm{HCl}$ acid medium.

b) The corrosion inhibition efficiency of the three inhibitors increases sharply with increasing concentration.

c) Adsorption of these three inhibitions follows Langmuir isotherms indicate that the adsorption of inhibitor on surface is a spontaneous process, involving Physisorption for $\mathbf{T Z} \mathbf{Z}_{\mathbf{A C I}}$ and chemisorption for the both $\mathbf{T} \mathbf{Z}_{\mathbf{C D I}}$ and $\mathbf{T} \mathbf{Z}_{\mathbf{C O I}}$.

d) Polarization studies revealed their mixed type nature inhibition for the three tested inhibitors.

e) EIS method shows that the charge transfer resistance $\left(\boldsymbol{R}_{\boldsymbol{c} t}\right)$ increases and double-layer capacitance $\left(\boldsymbol{C}_{\boldsymbol{d l}}\right)$ decreases in presence of the three inhibitors, suggesting the increasing surface coverage by the inhibitors molecules on the surface of mild steel.

f) SEM confirmed the absorption of 5-Chloroisatin derivatives molecules on the surface.

\section{References}

1. Subramanian, G.; Kannan, R.S.; Malarvizhi, M.; Muthirulan, P. J. Chem. Pharm. Res. 2018, 10, 155163.

2. Öztürk, S.; Mudaber, S.; Yildırım, A. JOTCSA. 2018, 5, 333-346. DOI: http://dx.doi.org/10.18596/jotcsa.309423

3. Liu, P.; Fang, X.; Tang, Y.; Sun, C.; Yao, C. Mater. Sc. Apps, 2011, 2, 1268-1278. https://doi.org/10.4236/msa.2011.29171

4. Tribak, Z.; Skalli, M.K.; Senhaji, O.; Rodi, Y.K.,; Haoudi, A.; Essassi, E.M. Am. Int. J. Res. Formal, Appl. Nat. Sci. 2017, 19, 41-50.

5. Tribak, Z.; Skalli, M.K.; Senhaji, O. Inter. J. Adv. Eng. Manag. Sc. 2017, 3, 882-885 Doi:10.24001/ijaems.3.8.11

6. Tribak, Z.; Ghibate, R.; Skalli, M.K.; Rodi, Y.K.; Mrani, D.; Aouniti, A.; Hammouti, B.; Senhaji, O. J. Eng. Res. Appl. 2017, 7, 2248-962204 DOI: https://doi.org/10.9790/9622-0704010408

7. Tribak, Z.; Skalli, M.K.; Senhaji, O.; Rodi, Y.K. Inter. J. Appl. Chem. 2017, 4, $2-7$.

8. Tribak, Z. Arc. Org. Inorg. Chem. Sci. 2019, 4. DOI: https://doi.org/10.32474/AOICS.2019.04.000177

9. Tribak, Z.; Skalli, M.K.; Senhaji, O. J. Biotech. Biores. 2019, 1.

10. Tribak, Z.; Skalli, M.K.; Senhaji, O. Anticorrosion Activity for Some 5-Chloroisatin Derivatives. Ed. Univ. Eur. 2017, 1-46.

11. Tribak, Z.; Chda, A.; Skalli, M.K.; Haoudi, A.; Rodi, Y.K.; Senhaji, O.; Essassi, E.M.; Cheikh, R. Ben; EL Abida, K. Int. J. Chem. Technol. 2018, 2, 105-115. DOI: https://doi.org/10.32571/ijct.446539

12. Tribak, Z.; Skalli, M.; Haoudi, A.; Rodi, Y.K.; Senhaji, O.; Essassi, E. J. Appl. Microbiol. Biochem. 2018, 1-4. DOI: https://doi.org/10.21767/2576-1412.100023

13. Tribak, Z.; El Amin, O.; Skalli, M.K.; Senhaji, O.; Rodi, Y.K.; Iraqui, M.H. Int. J. Eng. Res. Appl. 2017, 21-24.

14. Tribak, Z.; Amin, O. El; Skalli, M.K.; Senhaji, O.; Rodi, Y.K.; Iraqui, M.H. Int. J. Eng. Res. Appl. 2017, 66-70. DOI: https://doi.org/10.9790/9622-0706046670 
15. Tribak, Z.; Kandri Rodi, Y.; Haoudi, A.; Essassi, E.M.; Capet, F.; Zouihri, H. IUCrData. 2016, 1, x160862.

16. Tribak, Z.; Haoudi, A.; Kandri Rodi, Y.; Elmsellem, H.; Skalli, M.K.; Ouzidan, Y.; Mazzah, A.; Essassi, E. J. Chem. 2016, 4, 1157-1163.

17. Tribak, Z.; Kandri Rodi, Y.; Haoudi, A.; Essassi, E.M.; Capet, F.; Zouihri, H. IUCrData. 2016, 1, x160854.

18. Tribak, Z.; Kandri Rodi, Y.; Haoudi, A.; Essassi, E.M.; Capet, F.; Zouihri, H. IUCrData. 2016, 1, x160971.

19. Tribak, Z.; Kandri Rodi, Y.; Haoudi, A.; Essassi, E.M.; Capet, F.; Zouihri, H. IUCrData. 2016, 1, x160913.

20. Tribak, Z.; Rodi, Y.K.; Elmsellem, H.; Haoudi, A.; Skalli, M.K.; Ouzidan, Y.; Senhaji, O.; Sebbar, N.K.; Essassi, E.M.; Hammouti, B. J.Mar.Chim. 2017, 16, 157-165.

21. Tribak, Z.; Kharbach, Y.; Haoudi, A.; Skalli, M.K.; Kandri Rodi, Y.; El Azzouzi, M.; Aouniti, A.; Hammouti, B.; Senhaji, O. J. Mater. Environ. Sci. 2016, 7, 2006-2020.

22. Tribak, Z.; Kandri Rodi, Y.; Elmsellem, H.; Abdel-Rahman, I.; Haoudi, A.; Skalli, M.K.; Kadmi, Y.; Hammouti, B.; Ali Shariati, M.; Essassi, E.M. J. Mater. Environ. Sci. 2017, 8, 1116-1127.

23. Tribak, Z.; Haoudi, A.; Skalli, M.K.; Rodi, K.Y.; El Azzouzi, M.; Aouniti, A.; Hammouti, B.; Senhaji, O. J. Mater. Environ. Sci. 2017, 8, 299-309.

24. Tribak, Z.; Skalli, M.K.; Senhaji, O.; Rodi, Y.K. Inter J. Sc. Techn. Eng. 2016, 3, 257-262.

25.Zulfareen, N.; Venugopal, T.; Kannan, K. Inter. J. Corr. 2018, 1-18.

26. Fouda, A.S.; Rashwan, S.; Emam, A.; El-Morsy, F. E. Int. J. Electrochem. Sci. 2018, 13, 3719 - 3744. doi: $10.20964 / 2018.04 .23$

27. Singh, A.; Ansari, K.R.; Quraishi, M.A.; Lgaz, H.; Lin, Y. J. Alloys Compd. 2018, 762, 347-362.

28.Zoubi, W. Al; Ko, Y.G. Sci. Rep. 2018, 1-11. DOI: https://doi.org/10.1038/s41598-018-29299-5

29. Ansari, K.R.; Quraishi, M.A.; Singh, A. Corros. Sci. 2014, 79, 5-15.

30. Chaitra, T.K., Mohana, K.N., Tandon, H.C. Arab J. Basic Appl. Sci. 2018, 25, 45-55. DOI: https://doi.org/10.1080/25765299.2018.1449347

31. Soltani, N.; Salavati, H.; Rasouli, N.; Paziresh, M.; Moghadas, A. Chem. Eng. Commun. 2016, 203, $840-854$.

32. Solmaz, R.; Altunbas, E.; Kardas, G. Mater. Chem. Phys. 2011, 125, 796-801.

33. Doner, A.; Kardas, G. Corros. Sci. 2011, 53, 4223-4232.

34. Lakhrissi, B.; Touhami, M.E. Analytical \&. 2018, 10, 111-135.

35. Haque, J.; Verma, C.; Srivastava, V.; Quraishi, M.A. Results Phys. 2018, 9, 1481-1493. DOI: https://doi.org/10.1016/j.rinp.2018.04.069

36. Ansari, K.R.; Quraishi, M.A.; Singh. Measurement 2015, 76, 136-147. 